\title{
Kajian Bisnis Plan PT CAP Tentang Hunian Rumah Di Kelurahan Semanan Jakarta Barat Tahun 2020-
} 2024

\author{
Dede Hermawan. ${ }^{1}$, Dr. Tina Rosa, S.Sos., MM., M.si. ${ }^{2}$, dan Dr. Tri Suratmi, M.Pd. ${ }^{3}$ \\ Mahasiswa Program Studi Administrasi Bisnis Program Magister \\ Fakultas Pascasarjana Universitas Respati Indonesia \\ Dede78hermawan@gmail.com
}

\begin{abstract}
This research is an operational research (OR) predictive study, intended to make calculations about the feasibility of a business plan by taking various factors into account. The approach used is qualitative, to study the business plan made by PT CAP in carrying out business expansion in the field of propretion in the West Jakarta area.From the results of the research that has been done by the author, obtained by the payback period obtained normal alternatives to normal 36 months, optimistic alternatives 24 months. This result is much smaller than the management's stipulation of 4 years, so this project deserves to be accepted. Net Present Value Analysis, from the results of the NPV cash flow calculation is still much greater than the NPV cash outflow, meaning that the NPV assessment is that this project is considered very feasible to be implemented. The Internal Rate of Return (IRR) of this project is feasible because if you look for the IRR, the normal and optimistic alternatives are greater than the Weighted average cost of capital (WACC). Based on the results of the analysis and calculations that have been carried out by the author in relation to the Citra Garden Puri Semanan residential area project in Semanan, West Jakarta, the investment is generally considered feasible and profitable not only for the developer but also for the consumer who buys a house in the project. .
\end{abstract}

Keywords: Payback period, NPV, IRR

\begin{abstract}
Abstrak
Penelitian ini merupakan penelitian operasional (OR) prediktif studi, dimaksudkan untuk membuat perhitungan tentang kelayakan rencana bisnis dengan mempertimbangkan berbagai faktor. Pendekatan yang digunakan adalah kualitatif, untuk mengkaji rencana bisnis yang dibuat oleh PT CAP dalam melakukan ekspansi bisnis di bidang propresi di wilayah Jakarta Barat.Dari hasil penelitian yang telah penulis lakukan, didapatkan payback period didapatkan alternatif normal normal 36 bulan, alternatif optimis 24 bulan. Hasil ini jauh lebih kecil dari ketentuan manajemen 4 tahun, sehingga proyek ini layak untuk diterima. Analisis Net Present Value, dari hasil perhitungan NPV cash flow masih jauh lebih besar dari NPV cash outflow, artinya dari penilaian NPV proyek ini dinilai sangat layak untuk dilaksanakan. Internal Rate of Return (IRR) proyek ini layak dilakukan karena jika mencari IRR, alternatif normal dan optimistis lebih besar daripada Weighted average cost of capital (WACC). Berdasarkan hasil analisis dan perhitungan yang telah dilakukan penulis sehubungan dengan proyek kawasan perumahan Citra Garden Puri Semanan di Semanan, Jakarta Barat, secara umum investasi tersebut dinilai layak dan menguntungkan tidak hanya bagi pengembang tetapi juga bagi konsumen yang membeli rumah di proyek tersebut. . Memperhatikan apa yang telah dianalisis dan dibahas, maka saran penulis adalah mengecek kembali arus kas dengan mempertimbangkan mencari alternatif pendanaan dengan pinjaman yang meningkat sehingga biaya modalnya kecil.
\end{abstract}

Kata kunci: Payback period, NPV, IRR 


\section{Pendahuluan}

Rumah merupakan kebutuhan dasar yang sangat penting bagi manusia. Pertumbuhan penduduk di kota-kota besar terus meningkat menuntut kebutuhan ruang yang terus menerus bertambah, pada masyarakat Indonesia. Rumah tinggal merupakan cerminan jati diri manusia, namun terdapat klasifikasi rumah berdasarkan kelasnya yaitu kelas bawah, menengah dan kelas atas. Kelas menengah menjadi daya tarik tersendiri dimana merupakan katagori golongan ekonomi mampu dalam finansial dan menuntut akan fasilitas yang memadai yang perlu disediakan oleh developer.

Awal mulainya rumah ditujukan sebagai pemuas kebutuhan hidup manusia atas tempat tinggal yang aman, nyaman dan tenang.
Namun saat ini kepemilikan rumah tidak hanya ditujukan untuk pemenuhan kebutuhan pokok akan papan saja,melainkan telah menjadi suatu alternative investasi yang cukup menarik,dengan pengembalian berupa penghasilan sewa ataupun peluang keuntungan yang berupa capital gain yang merupakan selisih antara harga beli dengan harga jual ketika rumah tersebut terjual. Rumah juga merupakan indicator indentitas status social di masyarakat,jika sesorang memiliki yang mewah si pemilik merupakan orang yang berkemampuan tinggi. Dewasa ini telah berkembang berbagai jenis rumah 
dari yang modern seperti kondominium dan apertemen sampai jenis yang sederhana seperti rumah susun sederhana dan rumah biasa.

Menurut Undang-undang nomor 4 tahun 1992 tantang perumahan dan pemukiman Kementerian Negara Perumahan Rakyat Republik Indonesia menyatakan bahwa perumahan adalah kelompok rumah yang berfungsi sebagai lingkungan tempat tinggal atau lingkungan hunian yang dilengkapi dengan sarana dan prasarana lingkungan, sedangkan pemukiman adalah bagian dari lingkungan di luar kawasan lindung, baik yang berupa kawasan perkotaan maupun pedesaan yang berfungsi sebagai lingkungan yang mendukung perikehidupan dan penghidupan.

$$
\text { Menurut keputusan Menteri }
$$

Pemukiman dan Prasarana wilayah Nomor:217/KPTS?2002, rumah merupakan salah satu kebutuhan dasar manusia disamping pangan, sandang, pendidikan dan kesehatan. Selain berfungsi sebagai pelindung terhadap gangguan alam/cuaca dan mahluk lainnya,rumah juga memiliki peran social budaya sebagai pusat pendidikan keluarga,persemaian budaya dan nilai kehidupan,penyiapan generasi muda sebagai manifestasi jati diri. Eksklusivitas rumah perlu yang dipertimbangan, ketika muncul opini bahwasannya semakin dekat dengan pusat kota, maka semakin mahal harga dan sewa rumah. Akibatnya hanya orang-orang kaya yang dapat berlokasi di pusat kota, sementara orang berpenghasilan menengah kebawah hanya mampu menempati kawasan pinggiran kota. Disatu sisi hal ini sesuai dengan kemampuan mereka akan tetapi di sisi lain mereka harus menanggung biaya transportasi dan waktu yang lebih lama untuk berpergian ke pusat kota yang merupakan pusat kegiatan ekonomi dengan berbagai fasilitas pelayanan. Fenomena ini merupakan suatu paradox perumahan yang terjadi di negara berkembang yang menyimpang dari teori yang menyatakan bahwa semakin meningkatnya pendapatan,akan semakin banyak orang bermukim di pinggiran kota.

Menurut data yang didapat dari badan Pusat Statistik 2019, persentase rumah tangga di DKI Jakarta paling banyak tinggal dikediaman milik sendiri sebanyak $47,12 \%$. Namun masih banyak rumah tangga yang tinggal dikediaman yang membayar sewa/kontrak sebanyak $36,36 \%$ sedangkan menurut luas lantai rumah terluas, rata-rata rumah tangga di DKI Jakarta memiliki luas lantai rumah sebesar 20-49 m2 (35,55\%). Komposisi bangunan tempat tinggal rumah tangga di DKI Jakarta didominasi oleh atap yang terbuat dari asbes $(57,12 \%)$ dan genteng $(36,26 \%)$, dinding yang terbuat dari tembok $(95,47 \%)$ dan lantai yang terbuat dari keramik $(85,26 \%)$. Hanya sedikit bangunan yang terbuat dari bahan lain,hal ini disebebkan karena infrasturktur di DKI Jakarta sudah lebih maju jika dibandingkan dengan daerah lain di Indonesia.Presentasi rumah tangga di DKI Jakarta paling banyak menggunakan gas LPG sebagai bahan bakar utama untuk memasak sebesar $88,55 \%$, banyak juga persentase rumah tangga yang tidak memasak dirumah sbesar $8,23 \%$, contohnya rumah tangga yang seluruh anggota keluarganya bekerja. Namun masih ada rumah tangga yang menggunakan bahan bakar utama untuk memasak selain gas LPG yaitu minyak tanah $(1,5 \%)$, listrik $(1,11 \%)$,gas kota/biogas $(0,59 \%)$ dan kayu bakar $(0,02 \%)$.

Kondisi tersebut berpotensi dimanfaatkan oleh pengembang di daerah sekitar untuk mengusahakan adanya rumah tinggal. Melihat dari kondisi perkembangan permukiman di pusat kota khususnya DKI Jakarta masih banyaknya kebutuhan hunian kelas menengah keatas yang semakin tinggi. Perkembangan pemukiman di Jakarta sudah melaju pesat saat ini dilihat dari sebuah marketplace di internet.banyaknya iklan yang menjual rumah landed baru dengan kisaran 
harga yang bervariatif dan persebaran rumah bias diliat dari harga yang di tawarkan.

PT CAP merupakan salah satu pengembang perumahan yang mengkhususkan diri untuk menyediakan hunian kelas menengah ke atas di wilayah Jakarta. Dalam rangka memenuhi kebutuhan tentang rumah tinggal sesuai dengan harapan konsumen, perlu mengembangkan sebuah business plan dalam rangka bersaing dengan pengembang serupa di kawasan yang sama. Hal ini merupakan sebuah tantangan bisnis bagi pengembang untuk membuat perencanaan yang memadai sehingga PT CAP mampu bertahan, bahkan mengalami perkembangan pesat di tengah kerasnya persaingan bisnis.

Pada situasi Pandemic Covid 19 yang tidak pernah terpikirkan oleh semua pihak, dibutuhkan perhitungan yang lebih cermat dalam menyusun suatu perencanaan agar perusahaan tidak merugi. Kondisi financial yang dialami oleh masyarakat perlu disiasati oleh pengembang dengan tetap memberikan hunian yang berkualitas dengan mengurangi pagu anggaran yang tidak mendesak dibutuhkan.

\subsection{Rumusan Masalah dan Pertanyaan}

\section{Penelitian}

Rumah merupakan kebutuhan dasar manusia, selain sandang dan pangan. Penyediaan rumah bagi masyarakat bukan saja menjadi tanggungjawab pemerintah, namun memerlukan kontribusi dan keterlibatan pihak swasta yang kompeten. PT CAP merupakan salah satu pengembang property yang mengkhususkan diri pada penyediaan hunian kelas atas di kawasan DKI dan Banten. Dalam upayanya untuk berkembang dan mampu bersaing dengan pengembang lain, membutuhkan suatu kajian untuk jangka waktu tertentu dalam rangka pengembangan bisnis.
Berdasarkan rumusan masalah
tersebut, maka dapat diajukan pertanyaan penelitian sebagai berikut:

1. Berapa besar dana investasi yang dibutuhkan untuk membuat business plan selama 2020-2024?

2. Berapa lama (jangka waktu) investasi yang berupa uang tersebut dapat kembali?

3. Bagaimana kelayakan investasi PT CAP di lokasi di Perumahan Citra Puri Garden Semanan yang dijadikan obyek riset?

\subsection{Tujuan penelitian}

Tujuan umum:

Secara umum, penelitian dilakukan dengan tujuan untuk melakukan kajian terhadap kelayakan bisnis plan PT. Citra Adhi Pataka tahun 2020-2024

Tujuan khususnya:

Adapun tujuan khusus dari penelitian ini adalah:

1. Menghitung/mengkalkulasi besarnya dana investasi yang dibutuhkan untuk membuat business plan selama 20202024.

2. Menghitung/mengkalkulasi prediksi waktu yang diperlukan untuk mengembalikan investasi yang dikeluarkan PT CAP.

3. Mengkaji kelayakan investasi PT CAP di lokasi di Perumahan Citra Puri Garden Semanan yang dijadikan obyek riset.

\subsection{Manfaat Penelitian.}

1. Manfaat teoritis: dari aspek pengembangan bisnis perumahan, hasil penelitian ini dapat digunakan untuk memformulasikan strategi pengembangan pasar dan investasi.

2. Manfaat praktis: hasil penelitian inimerupakan bagian dari rencana perusahaan PT CAP sebagai acuan 
dalam melaksanakan operasional perusahaan.

\section{METODE PENELITIAN}

\subsection{Jenis Penelitian}

Penelitian ini merupakan riset operasional (OR) kajian prediktif, dimaksudkan untuk membuat kalkulasi tentang kelayakan sebuah rencana bisnis dengan memperhitungkan berbagai faktor. Pendekatan yang digunakan adalah kualitatif, untuk mempelajari busines plan yang dibuat oleh PT CAP dalam melakukan ekspansi bisnis dalam bidang propreti di kawasan Jakarta.

\subsection{Waktu dan Lokasi Penelitian}

Waktu penelitian direncanakan mulai bulan April 2020 sampai akhir bulan Mei 2020, dilakukan di Lokasi PT CAP berada yakni di Jakarta.

\subsection{Subyek dan Obyek Penelitian}

Subyek dalam penelitian ini adalah 5 orang informan yang dapat dijadikan sumber informasi tentang proyek PT CAP. Sedangkan obyek penelitian adalah Dokumen Busines plan PT CAP.

\subsection{Teknik Pengumpulan Data}

Data dalam penelitian ini adalah data primer dan sekunder. Data sekunder adalah berupa dokumen rencana bisnis (busines plan PT CAP di Jakarta, sedangkan data primer merupakan hasil kalkulasi yang dilakukan peneliti.

\subsection{Analisis Data}

Analisis data dengan menggunakan analisis isi (content analysis) dengan menggunakan standar perhitungan kelayakan usaha properti.

\section{HASIL PENELITIAN}

\subsection{Gambaran Umum Tempat Penelitian}

PT Ciputra Residence ("Perseroan") merupakan bagian dari Grup Ciputra yang bergerak dalam proyek pengembangan rumah hunian yang pada awalnya didirikan dengan nama PT Ciputra Habitat Industrial Estate Tangerang pada tahun 1989. Sebagai grup pengembang properti, Perseroan menjalankan kegiatan usaha yang meliputi penyediaan tanah, perencanaan, pelaksanaan pembangunan dan penjualan kawasan perumahan (real estate), perkantoran, pertokoan, pusat niaga beserta fasilitas sarana dan prasarananya. Pada tahun 1990, Perseroan melakukan perubahan nama menjadi PT Citraland Estate, kemudian berganti nama lagi pada tahun 1996 dan terakhir pada tahun 1999 masing-masing menjadi PT Ciputra Estate dan PT Ciputra Residence. Sebagian proyek Perseroan berlokasi di Jakarta dan Tangerang, dimana pada tahun 1989 Perseroan mengembangkan kawasan proyek perumahan yaitu Proyek CitraGarden City yang berlokasi dekat dengan Bandar Udara Internasional Soekarno Hatta. Pada tahun 1994, Perseroan membangun proyek CitraRaya Tangerang yang berlokasi di dekat jalan tol JakartaMerak. Selain kedua proyek tersebut, saat ini Perseroan juga telah mengembangkan berbagai proyek perumahan lainnya di wilayah Jakarta, Tangerang, Depok dan Cilegon yang ditujukan untuk berbagai segmen pasar yang berbeda mulai dari hunian untuk keluarga berpenghasilan menengah ke bawah dengan harga terjangkau, hingga hunian premium untuk rumah tangga menengah ke atas. Perseroan juga tengah melakukan ekspansi ke luar pulau Jawa seperti Jambi dan Palembang. Dengan persediaan lahan 
yang luas, Perseroan diuntungkan dengan adanya potensi peningkatan nilai tambah tanah yang sangat tinggi seiring berjalannya waktu. Hal ini tentunya akan memberikan dampak positif bagi prospek usaha Perseroan sebagai bekal keberlanjutan usaha properti di Indonesia. Saat ini Perseroan menaungi 28 (dua puluh delapan) Entitas Anak, 12 (dua belas) entitas dengan kepemilikan tidak langsung melalui Entitas Anak, 3 (tiga) Entitas Joint Venture dan 2 (dua) Entitas Asosiasi. Perseroan memiliki landasan yang kuat untuk menjadi pengembang berkualitas dalam menggarap pasar properti di Indonesia dengan berbekal pengalaman di bidang properti selama 25 tahun.

Ciputra Group salah satu developer besar yang membangun Citra Garden City, atau yang lebih dikenal dengan nama perumahan Citra. Ciputra Residence telah dikenal di masyarakat sebagai pemukiman yang ternama serta standar tinggi dan integritas perusahaan. Perumahan yang dikembangkan sekitar tahun 1980an sampai sekarang ini, memiliki beberapa project, dari Perumahan Citra $1-8$, dan Aeroworld 8. Citra Garden ini merupakan perumahan yang menyasar bagi masyarakat menengah dan menengah atas. Perumahan Citra ini telah berkembang menjadi kota mandiri di daerah Jakarta Barat. Perumahan Citra Garden ini sudah membangun sekitar 10 ribu rumah, dan telah mencapai 90\% tingkat huniannya. . Ciputra Group akan meluncurkan produk hunian eksklusif di area Jakarta Barat, tepatnya di Citra Puri Garden. Salah satu inovasi produk juga yang dicoba rilis ke market. Produk ini diharapkan bisa memenuhi kebutuhan rumah para millenials dengan harga di bawah Rp1 miliar di Jakarta. Progress pengembangannya masih dalam persiapan dengan lahan sekitar $17 \mathrm{Ha}$ dengan investasi dana kurang lebih 500 milyar rupiah. Lokasi Citra Puri Garden dikelilingi banyak perumahan yang sudah ada. Sebut saja perumahan Kosambi Baru yang sudah ada dari sekitar tahun 1990an. Ada juga perumahan yang baru berkembang seperti Metland Cyber City, Riviera Puri, Green Lake City yang menjadi landmark daerah sekitar, dll. Citra Puri Garden ini hanya 5 menit dari perumahan GLC dan stasiun kereta Kalideres. 10 menit dari perumahan Riviera at Puri, rumah sakit Mandaya Hospital, dan gerbang tol Karang Tengah (tol Jakarta Merak). 17 Menit ke Mall Puri Indah, Lippo Mall Puri, dan CBD Jakarta Barat. 30 menit dari Bandara Soekarno Hatta.

\subsubsection{Visi dan Misi Perusahaan}

a) Visi

Menjadi pengembang hunian dan area komersial yang inovatif dan terdepan di Indonesia dengan pangsa pasar yang patut diperhitungkan.

b) Misi

Pengembang yang berfokus pada pengembangan hunian terpadu berskala besar dan cadangan lahan yang besar dalam rangka memastikan kelangsungan operasi bisnis jangka panjang. Pencapaian skala ekonomis dan sinergi di antara hunian, komersial dan fasilitas-fasilitas lainnya yang dapat menciptakan keunggulan yang komparatif.

\subsubsection{Tujuan Perusahaan}

Tujuan Perusahaan menjadi 
perusahaan pengemabang hunian yang terbesar di Indonesia dan menciptakan Enterpreuner muda yang dapat memberi peluang lapangan kerja sebanyak-banyaknya.

\subsubsection{Struktur Organisasi Perusahaan}

$\begin{array}{ccc}\text { Struktur } & \text { organisasi } & \text { proyek } \\ \text { mempermudah } & \text { karyawan } & \text { dalam }\end{array}$ menjalankan pekerjaan sesuai dengan keahlian yang dimiliki serta kepada siapa karyawan itu akan bertanggung jawab. Struktur organisasi proyek juga memperjelas tugas, wewenang, tanggung jawab, dengan demikian akan membantu dalam mencapai suatu tujuan perusahaan. Berikut di bawah ini bagan struktur organisasi proyek secara umum, yang bisa kamu sesuaikan dengan kondisi di lapangan.

\section{Gambar 5.1 Struktur Organisasi}

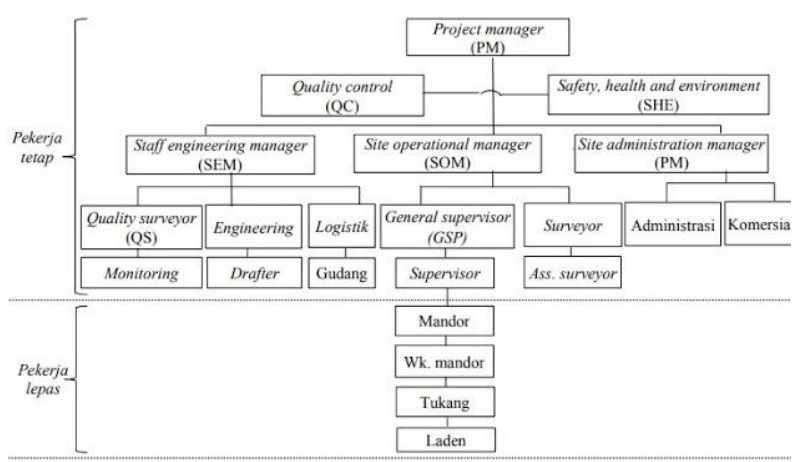

\subsubsection{Busines Plan PT CAP Tahun 2020-2024}

Sebagai bagian dari PT Ciputra Residence, semua ketentuan pokok di PT CAP dalam menyusun rencana bisnis mengacu pada semua standar yang berlaku di PT Ciputra Residence.

\subsubsection{Manajemen Operasional}

Manajemen operasional dalama perusahaan property berfungsi menyelenggarakan suatu system yang menyeluruh dan optimal yang terdiri:

\section{Tahap Pembuatan Desain}

Tahapan pertama dalam pembangunan proyek ini adalah membuat desain hotel yang akan dibangun. Desain ini dibuat berdasarkan lusanya lahan yang akan digunakan di untuk hotel ini. Desain yang dibuat terdiri dari beberapa bagian:

a. Desain Layout Lokasi

b. Desain Pekerjaan Civil

c. Desain Pekerjaan Mekanikal dan Elektrikal

d. Desain Pekerjaan Interior

Setelah desain ini jadi dan mendapat persetujuan dari para pemegang saham baru akan dilanjutkan dengan penentuan estimasi biaya dan estimasi waktu yang dibutuhkan untuk semua pekerjaan proyek tersebut di atas. Jika sudah didapat estimasi besarnya biaya dan estimasi waktu yang akan dibutuhkan untuk proyek ini maka akan dilakukan penunjukan kontraktor dengan menggunakan sistem tender terbuka.

Dari desain yang telah dibuat dan disetujui maka desain tersebut dapat digunakan untuk tahap selanjutnya yaitu tahap perijinan. sudah didapat estimasi besarnya biaya dan estimasi waktu yang akan dibutuhkan untuk proyek ini maka akan dilakukan penunjukan kontraktor dengan menggunakan sistem tender terbuka.

Dari desain yang telah dibuat dan disetujui maka desain tersebut dapat digunakan untuk tahap selanjutnya yaitu tahap perijinan. 


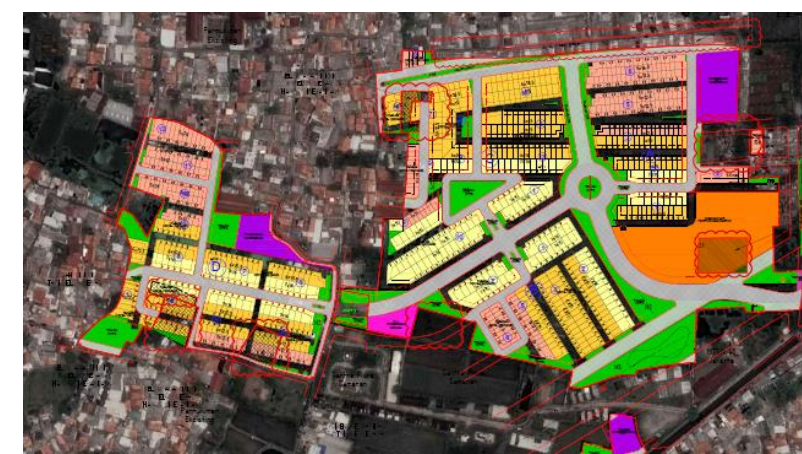

Gambar 5.3 Rencana Lokasi Proyek PT CAP

\section{Tahap Pelaksanaan Proyek}

Citra Puri Garden memiliki beberapa keistimewaan:

a. Memiliki area hijau yang luas sehingga membuat kawasan ini sejuk, rindang dan memiliki udara segar. Dari total area 18 hektar, kawasan ini memiliki area hijau sebanyak 2.4 hektar.

b. Menggunakan Auto-Gate Security Sytem dengan CCTV 24 jam. Pintu gerbang otomatis khusus untuk penghuni dengan menggunakan kartu RFID.

c. Menggunakan Double Gate Sytem dimana disini tamu dapat disortir oleh petugas keamanan agar lingkungan kawasan tetap aman dan nyaman.

d. Setiap rumah sudah dilengkapi dengan Digital Smart Door Lock System pada pintu utamanya.

Di Citra Garden City tersedia beberapa fasilitas seperti:

a. Concierge

Di CitraGarden Puri anda dapat memanfaatkan jasa Concierge, dimana layanan yang disediakan mulai dari Housekeeping, Maintenance
Service dan Estate Management. Semua ini dapat diakses dari aplikasi di handphone anda.

b. Laundry Room

Kalau anda malas mencuci sendiri, tidak perlu jauh-jauh keluar komplek, karena di CitraGarden Puri tersedia fasilitas Laundry Room.

c. Co-Working

Space

Meeting dengan klien atau sekedar berkumpul dengan teman tidak perlu cari-cari tempat yang pas karena di CitraGarden Puri sudah disediakan tempat yang cozy.

d. Self Storage

Service.

Tidak ingin rumah menjadi gudang? Tenang, di CitraGarden Puri disediakan layanan Self Storage dimana anda bisa menyimpan barangbarang anda dengan aman disini.

Untuk fasilitas di dalam kawasan tersedia

a. Club House dengan fasilitas Gym Indoor, Kolam Renang Semi Olympic, Hall (Community Center), Cafe, Mini Market, dan lain-lain

b. Jogging Track Sepanjang 2 kilometer mengelilingi kawasan

c. Bicycle Track untuk anda yang hobi bersepeda anda bisa memanfaatkan jalur khusus ini

d. Taman Bermain Anak tempat yang pasti akan menjadi favorit buah hati anda tercinta 
e. Outdoor Gym tempat anda dapat berolah raga supaya tubuh sehat dan bugar

\section{Strategi Penelitian}

Untuk menghadapi persaingan dalam suatu industri M. E. Porter memberikan tiga pendekatan strategi generik (generic strategy) yang secara potensial akan berhasil mengungguli perusahaan lain dalam suatu industri, tiga pendekatan tersebut adalah: Keunggulan Biaya (Cost Leadership), Differensiasi (Differensiation), dan Fokus (Focus Low Cost and Differensiation).

\subsection{Analisis Keuangan}

Dalam menganalisis investasi keuangan ada beberapa metode yang dapat digunakan untuk menilai kelayakan investasi diataranya dengan metode Rate of Return, metode Payback Periode, metode Net Present Value, metode Internal Rate of Return dan metode Profitability Index (DeFranco \& Lattin, 2007). Dari semua metode yang ada, yang biasa dipergunakan dalam menghitung suatu kelayakan investasi adalah metode Net Present Value (NPV), metode Internal Rate of Return ditambahkan dengan metode Payback Periode untuk menghitung jangka waktu pengembalian investasi, yang akan dipakai untuk merepresentasikan secara singkat analisi keuangan dalam tesis ini.

\subsubsection{Income Statement}

Income Statement Citra Puri Garden sering disebut juga sebagai profit and loss statement yang menyajikan hasil usaha selama periode tertentu, biasanya satu bulan, kwartal atau tahun (DeFranco \& Lattin, 2007). Income Statement biasanya di bagi menjadi dua bagian yaitu bagian pendapatan (revenue) dan bagian biaya operasi (operating expenses). Pendapatan yang dihasilkan didapatkan dari hasil penjualan, kelompok utama dalam penjualan dibedakan menjadi penjualan rumah,kavling,penyewaan lokasi tenan dan penghasilan lainnya seperti IPL (Iuran Pemeliharaan Lingkungan) yaitu biaya kebersihan, security, dan keindahan. Sedangkan biaya operasi (operating expenses) adalah pengeluaran yang langsung dikeluarkan sehari-hari untuk opeasional kawasan hunian, seperti marketing, COGS (cost of good sold), gaji karyawan, biaya marketing, biaya perbaikan, biaya energi, yang juga biasa disebut dengan (controllable expenses). Investasi untuk membangun sebuah kawasan hunian sangat besar dan termasuk investasi jangka panjang. Oleh karena itu dalam membuat proyeksi income statement dibuat untuk jangka waktu 4 tahun dimulai awal tahun 2020. Karena rencana pembangunan kawasan hunian ini membutuhkan waktu kurang lebih 4 tahun dan mulai dijalankan pada bulan Januari tahun 2020, maka diperkirakan pembukaan operasional kawasan hunian akan dimulai pada bulan Januari 2022, sehingga perhitungan proyeksi dimulai tahun 2021. Proyeksi income statement kawasan hunian ini.

\subsubsection{Perhitungan NPV}

Nilai yang pantas kita keluarkan untuk mendapatkan suatu nilai lain yang akan kita terima di masa yang 
akan datang disebut sebagai Nilai Sekarang (Present Value) dari jumlah tersebut. Sedangkan Nilai Bersih Sekarang (Net Present Value) dari suatu investasi modal adalah nilai sekarang dari suatu pemasukan tunai (cash inflow) dikurangi dengan nilai sekarang dari pengeluaran tunainya (DeFranco \& Lattin, 2007). Atau dapat juga dikatakan bahwan NPV adalah Jumlah kenaikan keuntungan yang didapatkan karena kita melakukan suatu investasi. Untuk menghitung nilai sekarang tersebut terlebih dahulu ditentukan tingkat suku bunga yang dianggap relevan, yaitu sesuai dengan tingkat pengembalian yang didapat jika dana tersebut kita tanamkan di deposito ataupun tabungan.

Apabila Nilai Sekarang penerimaan-penerimaan kas bersih dimasa yang akan datang lebih daripada nilai uang yang harusnya kita keluarkan saat ini untuk investasi, maka proyek ini dikatakan menguntungkan sehingga cukup layak untuk dilaksanakan dan proyek ini dikatakan merugi sehingga tidak layak untuk dilaksanakan adalah jikan NPV tersebut lebih kecil, atau biasa disebut NPV negatif. Dengan menggunakan rate of return sebesar 14\% yang diambil dari data Bank Indonesia untuk Surat Hutang Negara selama 10 tahun. Angka rate of return ini seperti yang dipersyaratkan oleh para pemegang saham. kas dengan rumus bunga bank sebesar $14 \%$ maka didapatlah nilai NPV sebesar Rp62.215.472.417 dalam tahun keempat dengan modal awal sebesar Rp 400.000.000.000 dan sesuai kaidah aturan NPV maka proyek investasi ini dapat dikatakan feasible untuk dilaksanakan.
Hasil dari nilai NPV dapat dilihat pada tabel di bawah ini.

Tabel 5.1

Hasil Perhitungan NPV

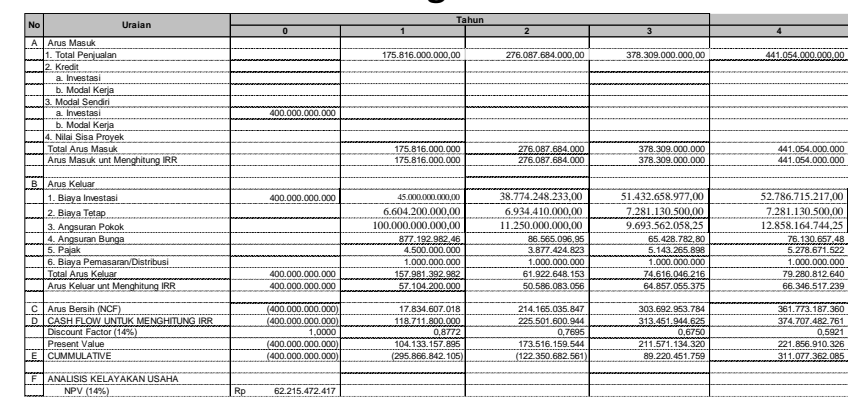

\begin{tabular}{|l|l|l|l|}
\hline & BP & 3,6 & \multirow{2}{*}{ bulan } \\
\hline & & 42,9 & \\
\hline
\end{tabular}

\subsubsection{Perhitungan Internal Rate of Return (IRR)}

Metode ini menghitung tingkat pengembalian (atau dapat dikatakan sebagai tingkat bunga) dari suatu rencana investasi yang dibandingkan dengan tingkat pengembalian minimum yang ditetapkan/ disayaratkan oleh perusahaan, yang biasanya berkisar pada tingkat bunga yang relevan dengan yang saat ini berlaku di pasar. Apabila tingkat pengembalian (tingkat bunga) ini lebih besar daripada tingkat bunga relevan seperti yang disyaratkan di atas, maka investasi dianggap menguntungkan dan layak untuk dilaksanakan. Sebaliknya jika tingkat pengembalian berada dibawah tingkat pengembalian yang ditetapkan maka investasi sebaiknya tidak dilaksanakan karena tidak menguntungkan (DeFranco \& Lattin, 2007).Nilai arus pengembalian internal atau Internal Rate of Return (IRR) dapat dihitung dengan menggunakan rumus yang terdapat pada Tabel di bawah ini. 
Tabel 5.2

Perhitungan Internal Rate of Return (IRR)

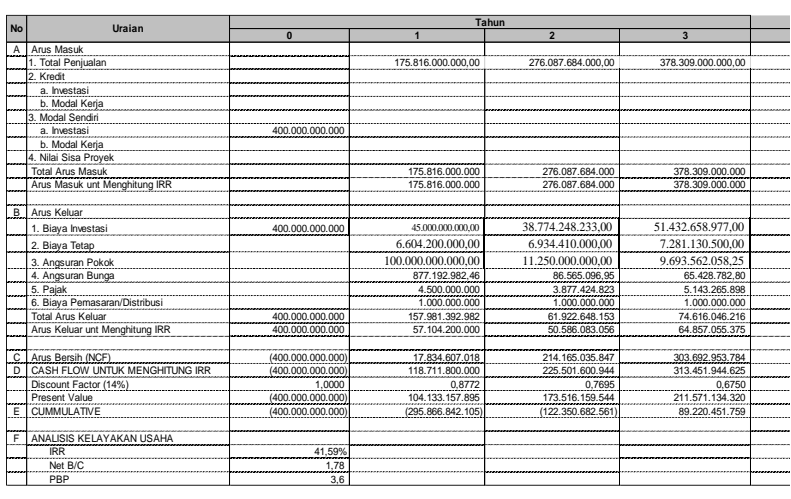

Sumber : diolah dari proyeksi income statement

Dengan menggunakan bantuan program Microsoft Excel maka didapatkan nilai arus pengembalian internal Internal Rate of Return (IRR) sebesar $41,59 \%$ pada tahun ke empat.

Ternyata nilai IRR ini berada di atas nilai Rate of Return yang dipersyaratkan oleh perusahaan yaitu sebesar $14 \%$. Maka proyek investasi ini dapat dikatakan menguntungkan ditinjau dari aspek finansial.

\subsubsection{Perhitungan Payback Periode}

Perhitungan nilai payback periode dilakukan dengan menjumlahkan nilai present value dari arus kas proyek yang masuk dan dibandingkan dengan investasi awal yang telah dilakukan sehingga didapatkan lamanya waktu yang dibutuhkan untuk mendapatkan kembali investasi awal tersebut (DeFranco \& Lattin, 2007). Perhitungannya dapat dilihat pada Tabel 4.15 dibawahini:

Tabel 5.3

Perhitungan Payback Periode

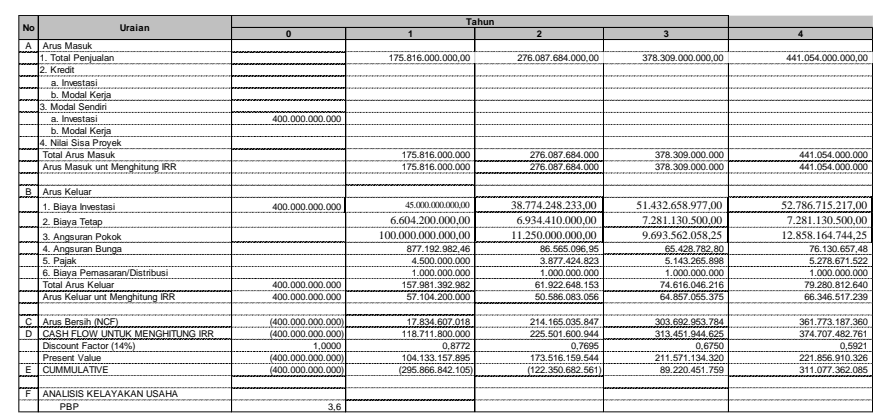

Sumber : diolah dari proyeksi income statement

Melihat lamanya periode pengembalian ini tentunya harus kembali melihat industri apa yang sedang dimasuki. Dalam industri perhotelan, hampir semua bersifat long term investment (investasi jangka panjang) sehingga periode selama 3,6 tahun atau 40 bulan masih termasuk baik dan dapat diterima oleh PT.CAP.

\subsection{Analisis Sensitivitas}

Analisis sensitivitas ini dilakukan untuk mengetahui atau memberikan gambaran sampai sejauh apakah analisis keuangan pada proyek pembangunan kawasan hunian ini cukup kuat untuk berhadapan dengan perubahan faktor-faktor yang mempengaruhinya Analisa sensitivitas dilakukan dengan mengubah nilai dari suatu parameter pada suatu saat untuk selanjutnya dilihat bagaimana pengaruhnya terhadap feasibility dari suatu alternatif investasi. Dalam hal ini analisis sensitivitas dilakukan dengan membuat dua skenario tambahan, yaitu skenario terburuk dan skenario terbaik. Dalam skenario terburuk ini asumsi tingkat kawasan hunian adalah 14 \%. 4.16 (Asumsi), Tabel dibawah ini:

Tabel 5.4

\section{Analisis Sensitivitas}




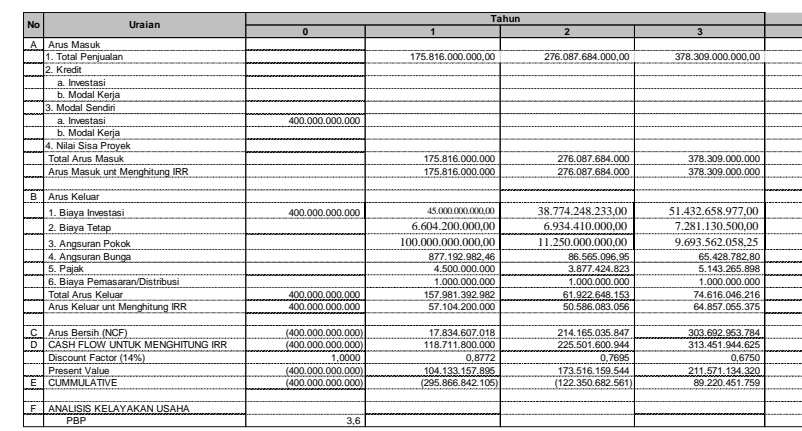

PEMBAHASAN

\subsection{Keterbatasan Penelitian}

Di dalam penelitian ini terdapat keterbatasan yang dapat diungkapkan, antara lain sebagai berikut:
1. Jenis penelitian merupakan penelitian operation riset prediktif dengan pendekatan kualitatif sehingga tidak bisa di generalisir untuk wilayah dan kawasan berbeda / tempat lain.

2. Dari sisi metode penelitian ini menggunakan pendekatan kuantatif sehingga data-data kualitatif tidak tergali.
3. Penelitian prediktif ketepatannya banyak dipengaruhi oleh situasi dan kondisi suatu kawasan.

\subsection{Kajian Secara Umum Busines Plan PT CAP}

Seiring dengan perbaikanperbaikan yang dilakukan pemerintah di segala bidang,perlahan membuat perekonomian Indonesia mulai jalan dan menggeliat lagi. Salah satu strategi yang mengguntungkan bagi para investor dan konsumen adalah tingkat suku bunga yang rendah, sehingga masyarakat lebih suka memutar uang daripada menyimpan diban. Kondisi seperti ini juga memberikan keuntungan bagi para pelaku bisnis dibidang perumahan yang menyebabkan permintaan akan rumah meningkat.

Karena permintaan yang meningkat inilah penulis ingin melakukan suatu analisa awal, analisa awal ini adalah suatu studi kelayakan pengembang kawasan yang menentukan apakah gagasan bisnis ini bisa dipertimbangkan dan layak untuk dilaksanakan.

\subsection{Analisis Payback Period}

Dengan perhitungan diatas, berarti payback period untuk alternative 1 normal ini adalah 40 bulan, untuk alternatif 2 optimis adalah 20 bulan. Semua hasil ini jauh lebih kecil dari ketetapan manajemen yang 4 tahun. Tetapi metode payback periode ini sangat sederhana sehingga mempunyai kelemahan. Kelemahan utama nya yaitu metode ini tidak memperhatikan konsep nilai waktu dari uang disamping juga tidak memperhatikan aliran kas masuk setelah payback. Jadi umumnya metode ini digunakan sebagai pendukung metode lain yang lebih baik.

Net Present Value (NPV).

Untuk menghitung NPV pada proyek ini, penulis menggunakan asumsiasumsi sebagi berikut:

1. Tingkat bunga yang diperoleh dari bank sebesar $14 \%$ dan tingkat kebijakan pemegang saham terhadap modal sendiri sebesar $15 \%$ maka Weihted Average cost of Capital (WACC) yang ditetapkan pada perhitungan NPV sebesai 15\% karena proyek ini menggunakan modal sendiri.

2. Menurut penilaian NPV bahwa proyek ini dianggap cukup layak untuk dilaksanakan dengan alternative terbaik adalah scenario normal dikarenakan akan adanya kenaikan nilai jual.

Internal Rate of Return (IRR)

Metode ini digunakan untuk mencari tingkat Bungan yang 
menyamakan nilai sekarang dari arus kas yang diharapkan di masa datang, atau penerimaan kas, dengan mengeluarkan investasi awal.

Dari hasil net cash flow yang di dapat IRR sebesar

1. Alternatif 1 normal $=89 \%$

2. Alternatif 2 Optimis $=96 \%$

IRR alternative 1 dan 2 lebih besar dari Weighted Average Cost Of Capital (WACC) sehingga layak dilaksanakn

Dari beberapa analisa penilaian investasi dengan perhitungan payback periode, Net Present Value, Internal Rate of Return dan Profitability Index, Kesemuanya menunjukan bahwa investasi di Citra Puri Garden Semanan di wilayah Jakarta Barat ini dianggap sebagai sangat layak untuk dilaksanakan.

Memperhatikan aspek marketing perlu dilakukan "marketing survey" secara lebih tajam lagi untuk menentukan positioning proyek dan target market serta pengembangan detail product sales yang sesuai dengan kawasan pelaksanaan market positioning tersebut dijalankan melalui:

1. Identifikasi keunggulan kompetitif yang memberikan nilai tambah terbesar dengan cara mengadakan: difrensiasi produk, difrensiasi jasa, difrensiasi personil dan difrensiasi citra

2. Memilih keunggulan kompetitif yang tepat, antara lain dengan mempromosikan apa saja perbedaan yang dimiliki

3. Mewujudkan dan mengkomunikasikan posisi yang dipilih

4. Menggunakan ke empat macam sarana promosi antara lain:
a. Iklan (Advertising)
b. Promosi penjualan
(Sales

\author{
Promotion) \\ c. Publisitas (Publicity) \\ d. Penjualan ke daerah-daerah \\ (Road show)
}

\section{KESIMPULAN DAN SARAN}

\subsection{Kesimpulan}

Berdasarkan hasil penelitian yang telah dipaparkan dan dibahas pada babbab sebelumnya dengan mengacu tujuan penelitian, maka dapat dibuat kesimpulan sebagai berikut:

1. Dana yang dibutuhkan untuk mewujudkan business plan PT CAP dalam membangun kawasan hunian perumahan di kawasan Jakarta Barat selama periode tahun 2020-2024 adalah sebesar Rp 773.800.899.992 (Tujuh Ratus Tujuh Puluh Tiga Milyar Delapan Ratus Juta Delapan Ratus Sembilan Puluh Sembilan Ribu Sembilan Ratus Sembilan Puluh Dua Rupiah).

2. Dana investasi yang dikeluarkan untuk membangun kawasan tersebut, sesuai dengan perhitungan dari semua variabel cost selama tahun 2020-2024 sebesar Rp 587.993.622.427 (Lima Ratus Delapan Puluh Tujuh Milyar Sembilan Ratus Sembilan Puluh Tiga Juta Enam Ratus Dua puluh Dua Ribu Empat Ratus Dua Puluh Tujuh Rupiah)

3. Busines plan PT CAP untuk mewujudkan kawasan hunian di Semanan Jakarta Barat dinyatakan layak (feasible).

\subsection{Saran}

Berdasarkan kesimpulan tersebut, maka dapat dibuat saran sebagai berikut: 
1. Memperkecil resiko kegagalan investasi dengan lebih berhati-hati terhadap segala jenis pengeluaran yang tidak perlu pada masa pandemi Covid-19 yang masih berlangsung sampai dengan bulan Agustus 2020 dan belum dapat diprediksi kapan berakhir.

2. Dari aspek marketing perlu melakukan "market survey" secara lebih tajam lagi untuk menetukan positioning proyek dan target market serta pengembangan detail product sales yang sesuai dengan kawasan.

3. Dari aspek teknik, harus mampu memberikan nilai tambah pada produk bangunan yang dihasilkannya, baik mengenai satuan harga dan alternative spesifikasi material yang digunakan maupun dari sisi metedologi dan kualitas pengawasan dari pekerjaan konstruksi bangunan ruma, pematangan lahan maupun prasarana lingkungan, karena kualitas bangunan dan prasarana lingkungan yang baik dapat meningkatkan nilai jual tersebut.

4. Dari aspek keuangan, melakukan pengecekan kembali terhadap cashflow yang sudah dibuat disesuaikan dengan strategi pemasaran, pencarian alternatif pendanaan dan monitoring efisiensi pengeluaran biaya-biaya yang muncul selama proyek berjalan.

\section{DAFTAR PUSTAKA}

Barney, J. B., (1991). Firm resources and sustained competitive advantage, Journal of Management, Vol. 17, pp.99-120.
Biro Pusat Statistik, Laporan Kunjungan Wisatawan Asing 2009, Jakarta : Biro Pusat Statistik, 2010.

Booms, B. H. and Bitner, M. J. (1981), "Marketing Strategies and Organization Structures for Service Firms," in Donnelly, J. H. and George, W. R. (Eds), Marketing of services, Chicago: American Marketing Association, pp. 47- 51.

Collis, D. J., (1994). Research note: How valuable are organisational capabilities, Strategic Management Journal, Vol. 15, pp.143- 152.

Davidoff, D.M. (1994). Contact: Customer service in the hospitality and tourism industry. New York: Prentice Hall.

DeFranco, A \& Lattin, T.,(2007). Hospitality financial management. New Jersey: John Wiley \& Sons, Inc.

Dessler, G., (2000). Human resource management. $8^{\text {th }}$ Ed., New Jersey: Prentice- Hall. Inc.

Ford, R. C. \& Heaton, C. P., (2000). Managing the guest experience in hospitality, Albany, New York: Delmar Publishers.

Ford, R. C. \& Heaton, C. P., (2001). Lessons from hospitality that can serve anyone, Organizational Dynamics Journal, Vol. 30, No. 1, pp. 30-47.

Foster, Dennis L., (1993). Rooms at the inn : Front office operation and administration. Singapore: Mc GrawHill International Editions.

Ghemawat, P., D. Collis, G. Pisano, and J. Rivkin. Strategy and the Business Landscape. Upper Saddle River, New Jersey: Prentice Hall.

Grant, R.M., (1991). The resource-based theory of competitive advantage: Implications for strategy formulation. California Management Review, Vol. 33, pp. 114-35

Grant, R.M., (2010). Contemporary strategy analysis, $7^{\text {th }}$ Ed., New York: John Wiley and Sons.

Gray, W. S. \& Liguori, S. C., (1994). Hotel and motel management and operations, $3^{\text {th }}$ Ed., New Jersey : Prentice Hall, Inc. 
Henderson, J.C., (2007). Corporate social responsibility and tourism: Hotel companies in Phuket, Thailand, after the Indian Ocean tsunami. Hospitality Management Journal, Vol. 26, pp. 228-239.

Henry, Anthony, (2007). Understanding strategic management, Oxford University Press.

Ivancevich, J. M.; Hoon, Lee Soon. (2002). Human Resource Management in Asia. Singapore : McGraw-Hill Education. A Division of The McGrow-Hill Companies.

Johnson, C. \& Vanetti, M., (2005). Locational Strategies of international Hotel Chains. Annals of Tourism Research, Vol. 32, No. 4, pp. 1077-1099.

Kasali, Rhenald. (1998). Membidik Pasar Indonesia: Segmentasi, Targeting, Positioning. PT. Gramedia Pustaka Utama.

Keiser, J.R., (1989). Principles and practices of management in the hospitality industry. $2^{\text {nd }}$ Ed, New York: Van NostrandReinhold.

Kotler P. and Keller K.L. (2006), Marketing Management, $12^{\text {th }}$ Edition, New Jersey : Prentice Hall.

Kotler, P., J. Bowen dan J. Makens. (1996). Marketing for Hospitality and Tourism. Prentice Hall, New York.

Kotler, Philip (1994). Marketing Management : Analysis, Planning, Implementation and Control. $8^{\text {th }}$ Ed. New Jersey: Prentice Hall, Inc. A Paramount Communications Company.

Kotler, Philip. 2009. Manajemen Pemasaran Edisi 12. Jakarta.

Kotler, Philip., dan Armstrong. 2013. Marketing Management. 15th Edition. Pearson Prentice Hill.

Kotler. (1997). Manajemen Pemasaran (Terjemahan), Jakarta: Preghallindo.

Lam, T. \& Han, M. X. J., (2005). A study of outsourcing strategy: a case involving the hotel industry in Shanghai, China. Hospitality Management Journal, Vol. 24, pp. 41-56.

Lane, Keller Kevin, (2008). Strategic brand mangement : Building, measuring and managing brand equity. $3^{\text {th }} \mathrm{Ed}, \mathrm{New}$ Jersey: Prentisce Hall.

Lewis, R. C. and Chambers, R. E., (1989). Marketing leadership in hospitality, New York: Van NostrandReinhold.

Li Song, (2008). An analysis on chinese hotel enterprises outsourcing strategic modes and corresponding development conception, International Journal of Business and Management, Vol. 3, No.3 pp. 76-81.

Lovelock, CH and Wirtz J. (2007). Services Marketing. $7^{\text {th }}$ Ed. United States of America: Pearson International Edition.

Magretta, J., (2002). Why business models matter, Harvard Business Review, Vol. 80, No 3. pp. 86-92

McCabe, V.S., (2008). Strategies for career planning and development in the Convention and Exhibition industry in Australia, Hospitality Management Journal, Vol. 27, pp. 222-231

Mittal, B., Baker, J., 2002. Advertising strategies for hospitality services: Because services are intangible, hospitality advertising must overcome the quadruple challenges of abstraction, generality, mental impalpability, and non- searchability. Cornell Hotel \& Restaurant Quarterly Journal, Vol. 43 (2), pp. 51-63.

Nebel, Eddystone C., (1991). Managing hotels effectively : Lessons from outstanding general managers, New York: Van NostrandReinhold.

Peteraf, M. A., (1993). The cornerstones of competitive advantage: A resourcebased view, Strategic Management Journal, Vol. 14, pp. 179-191.

Phillips, P. A., (1996). Strategic planning and business performance in the quoted UK hotel sector: Results of an exploratory study. Hospitality Management Journal, Vol. 15 No 4, pp. 347-362.

Pizam, A., (1993). Managing cross-cultural hospitality enterprises. In the international hospitality industry: Organizational and operational issues, 
Jurnal Administrasi Dan Manajemen

eds. London: P. Jones and A. Pizam.

Pitman Publishing.

Porter, M. E. (1980). Competitive Strategy:

Techniques for analysing industries and competitors. Free Press, New York.

Porter, M. E. (1985). Competitive advantage, The Free Press, New York, NY. Porter, M. E. (1996). What is strategy? Harvard Business Review, Vol 74(6). 